\title{
Homeostatic Switch in Hebbian Plasticity and Fear Learning after Sustained Loss of $\mathrm{Ca}_{\mathrm{v}} 1.2$ Calcium Channels
}

\author{
Nicole Langwieser, ${ }^{1 \star}$ Carl J. Christel, ${ }^{1 \star}$ Thomas Kleppisch, ${ }^{1}$ Franz Hofmann, ${ }^{3}$ Carsten T. Wotjak, ${ }^{2}$ and Sven Moosmang ${ }^{1}$ \\ ${ }^{1}$ Institute for Pharmacology, Technical University Munich, 80802 Munich, Germany, ${ }^{2}$ Max Planck Institute of Psychiatry, Neuroplasticity Group, 80804 \\ Munich, Germany, and ${ }^{3}$ Research Group 923, Technical University Munich, 80802 Munich, Germany
}

$\mathrm{Ca}^{2+}$ influx through postsynaptic $\mathrm{Ca}_{\mathrm{v}} 1 . x \mathrm{~L}$-type voltage-gated channels (LTCCs) is particularly effective in activating neuronal biochemical signaling pathways that might be involved in Hebbian synaptic plasticity (i.e., long-term potentiation and depression) and learning and memory. Here, we demonstrate that $\mathrm{Ca}_{\mathrm{v}} 1.2$ is the functionally relevant LTCC isoform in the thalamus-amygdala pathway of mice. We further show that acute pharmacological block of LTCCs abolishes Hebbian plasticity in the thalamus-amygdala pathway and impairs the acquisition of conditioned fear. On the other hand, chronic genetic loss of $\mathrm{Ca}_{\mathrm{v}} 1.2$ triggers a homeostatic change of the synapse, leading to a fundamental alteration of the mechanism of Hebbian plasticity by synaptic incorporation of $\mathrm{Ca}^{2+}$-permeable, GluA2-lacking AMPA receptors. Our results demonstrate for the first time the importance of the $\mathrm{Ca}_{\mathrm{v}} 1.2 \mathrm{LTCC}$ subtype in synaptic plasticity and fear memory acquisition.

\section{Introduction}

The role of $\mathrm{Ca}_{\mathrm{v}} 1 . \mathrm{x}$ L-type voltage-gated channels (LTCCs) in learning and memory is controversial. There is significant evidence indicating an important role of LTCCs in the activation of learning-related neural pathways, e.g., the cAMP response element-binding protein (CREB) or nuclear factor of activated T cells (NFAT) pathway (West et al., 2001; Deisseroth et al., 2003), and in Hebbian synaptic plasticity at glutamatergic synapses (Grover and Teyler, 1990; Weisskopf et al., 1999; Bauer et al., 2002; Moosmang et al., 2005). However, the LTCC subtype responsible in each case is not known.

Given these data and the fact that there is a direct causal link between Hebbian long-term potentiation (LTP) in the lateral amygdala (LA) and fear learning and memory (Sigurdsson et al., 2007), it is surprising that there are seemingly contradictory reports on the role of LTCCs in various fear-learning paradigms.

Bauer et al. (2002) showed that intra-amygdala infusion of LTCC blockers impaired acquisition of auditory fear memory, while studies that used peripheral infusion of LTCC blockers failed to find effects on fear memory acquisition (Cain et al., 2002; Suzuki et al., 2004). Genetic deletion of $\mathrm{Ca}_{\mathrm{v}} 1.2$ in the forebrain did not impair acquisition, consolidation, and extinction of contextual fear memory (McKinney et al., 2008). On the other hand, extinction of contextual fear memory has been shown to be impaired by LTCC blockers (Cain et al., 2002; Suzuki et al., 2004). To complicate matters, recently it has been postulated that block

Received Sept. 2, 2008; revised April 19, 2010; accepted April 22, 2010.

This work was supported by grants from Deutsche Forschungsgemeinschaft and Fonds der Chemischen Industrie. We thank Prof. Rüdiger Klein for the Nestin-Cre mice, Prof. Michael Frotscher for help with the brain morphology analysis, and Angelika Baumgartner for excellent technical assistance.

${ }^{*} N . L$. and C.J.C. contributed equally to this work.

Correspondence should be addressed to Sven Moosmang, Institut für Pharmakologie der Technische Universität München, Biedersteiner Straße 29, 80802 München, Germany. E-mail: moosmang@ipt.med.tu-muenchen.de DOI:10.1523/JNEUROSCI.4164-08.2010

Copyright $\odot 2010$ the authors $\quad 0270-6474 / 10 / 308367-09 \$ 15.00 / 0$ of LTCC signaling through $\mathrm{Ca}_{\mathrm{v}} 1.2$ after peripheral, not intracerebral, injection interferes with fear memory extinction, presumably via a peripherally mediated mechanism (Busquet et al., 2008; Waltereit et al., 2008). Here, we investigated the role of $\mathrm{Ca}_{\mathrm{v}} 1.2$ LTCCs in synaptic plasticity in the LA and extended these in vitro findings to animal behavior in an auditory fear-conditioning paradigm.

Collectively, our results show for the first time that the $\mathrm{Ca}_{\mathrm{v}} 1.2$ subtype of LTCCs in the LA is specifically responsible for fear memory acquisition and synaptic plasticity. Chronic loss of these channels, however, triggers a homeostatic change in the expression of postsynaptic $\mathrm{Ca}^{2+}$-permeable, GluA2-lacking AMPA receptors (cp-AMPARs) that maintains normal neuronal functioning.

\section{Materials and Methods \\ Mice}

Mice with C57BL/6JOlaHsd background were purchased from Harlan Winkelmann, transgenic mutant mice were bred at the Institut für Pharmakologie der Technische Universität München (Munich, Germany). $\mathrm{Ca}_{\mathrm{v}} 1.2 \mathrm{~L} 1$ and $\mathrm{Ca}_{\mathrm{v}} 1.2 \mathrm{~L} 2$ mice (Seisenberger et al., 2000) were backcrossed on a C57BL6 genetic background (for 10 generations). Conditional mouse mutants with an inactivation of the CACNA1C gene in the whole CNS were obtained using the cre-loxP system. Specifically, $\mathrm{Ca}_{\mathrm{v}} 1.2^{\mathrm{Nes} C r e}$ mice (genotype: $\mathrm{Ca}_{\mathrm{v}} 1.2 \mathrm{~L} 1 / \mathrm{L} 2$; Nestin-Cre Cre/+) (see Fig. $2 a$ ) and their litter-matched control siblings (genotype: $\mathrm{Ca}_{\mathrm{v}} 1.2+/ \mathrm{L} 2$; Nestin-Cre Cre/+) (see Fig. 2a) were obtained by crossing mice carrying two loxP-flanked ("floxed") $\mathrm{Ca}_{\mathrm{v}} 1.2$ alleles $\left(\mathrm{Ca}_{\mathrm{v}} 1.2 \mathrm{~L} 1\right.$ and $\left.\mathrm{Ca}_{\mathrm{v}} 1.2 \mathrm{~L} 2\right)$ with Nestin-Cre transgenic mice (Tronche et al., 1999) backcrossed on a C57BL/6 genetic background (for three generations). Only male mice were used for experiments (at the age of 8-12 weeks for behavioral experiments, 17-24 d old for brain slice experiments). Given the mixed genetic background of these $\mathrm{Ca}_{\mathrm{v}} 1.2$ mutant mice and to rule out unspecific effects of the Nestin-Cre transgene, littermate controls expressing Cre were used in all experiments involving genetic deletion of $\mathrm{Ca}_{\mathrm{v}} 1.2$. Mice with $\mathrm{C} 57 \mathrm{BL} / 6 \mathrm{JOlaHsd}$ background were used in all other experiments. 
Table 1. No difference in electrophysiological properties of LA pyramidal neurons

\begin{tabular}{|c|c|c|c|c|}
\hline & $\operatorname{Ctr}(\mathrm{BL} / 6)$ & Ctr (Nestin) & $10 \mu \mathrm{m}$ Isra $(\mathrm{BL} / 6)$ & KO \\
\hline Spiking threshold (mV) & $-43.06 \pm 1.13$ & $-42.98 \pm 1.12$ & $-41.06 \pm 1.17$ & $-43.30 \pm 0.54$ \\
\hline Resting potential (mV) & $-63.8 \pm 1.4$ & $-64.7 \pm 0.7$ & $-64.0 \pm 1.1$ & $-66.2 \pm 1.5$ \\
\hline Spiking latency (ms) & $185.2 \pm 32.9$ & $180.0 \pm 14.4$ & $150.4 \pm 19.3$ & $191.3 \pm 27.2$ \\
\hline Frequency adaptation & $1.36 \pm 0.16$ & $1.20 \pm 0.07$ & $1.39 \pm 0.11$ & $1.66 \pm 0.17$ \\
\hline Input resistance (M $\Omega$ ) & $284 \pm 37$ & $362 \pm 23$ & $226 \pm 16$ & $318 \pm 70$ \\
\hline
\end{tabular}

Pyramidal neurons from the different experimental groups were characterized by a current injection protocol in a LA slice preparation. Ctr (BL/6), Slices from control C57BL/6 mice ( $n=5$ ); Ctr (Nestin), slices from controls carrying the Nestin-Cre transgene $(n=6) .10 \mu \mathrm{m} \mathrm{Isra} \mathrm{(BL/6),} \mathrm{slices} \mathrm{from} \mathrm{Bl6} \mathrm{mice} \mathrm{superfused} \mathrm{with} 10 \mu \mathrm{m}$ isradipine $(n=5)$. K0, slices from Ca $1.2^{\text {Nescre }}$ knock-out animals. For each cell, the first current-injection trace that induced an action potential train of at least three spikes was analyzed for the threshold level for initiating a subsequent action potential (spiking threshold), resting potential, spiking latency, frequency adaptation, and input resistance (values are given as mean \pm SEM). None of the groups differed significantly in any of the parameters.

Animals were housed singly with food and water ad libitum under an inverse $12 \mathrm{~h}$ light/dark cycle (lights off, 9:00 A.M.) for at least $14 \mathrm{~d}$ before starting the experiments. All experiments were approved by the Committee on Animal Health and Care of the State of Bavaria (Government of Oberbayern, Germany) and performed in strict compliance with the European Economic Community recommendations for the care and use of laboratory animals.

All behavioral experiments were performed with different batches of animals during the activity phase of the mice between 9:30 A.M. and 5:00 P.M.; experimenters were unaware of the genotype/treatment.

\section{Brain slice preparations}

Mice (17-24 d old) were anesthetized with diethylether and the brains were removed and transferred to ice-cold artificial CSF (ACSF). In case of LTP and AMPAR experiments, ACSF contained the following (in $\mathrm{mm}$ ): 10 glucose, $124 \mathrm{NaCl}, 3 \mathrm{KCl}, 26 \mathrm{NaHCO}_{3}, 1.25 \mathrm{KH}_{2} \mathrm{PO}_{4}, 2$ $\mathrm{CaCl}_{2}, 1 \mathrm{MgSO}_{4}{ }^{*} 7 \mathrm{H}_{2} \mathrm{O}$, gassed with $95 \% \mathrm{O}_{2} / 5 \% \mathrm{CO}_{2}$. In case of $\mathrm{Ba}^{2+}$ current recordings, ACSF contained the following (in $\mathrm{mm}$ ): 10 glucose, $124 \mathrm{NaCl}, 3 \mathrm{KCl}, 26 \mathrm{NaHCO}_{3}, 1.25 \mathrm{KH}_{2} \mathrm{PO}_{4}, 2 \mathrm{BaCl}^{\star} 2 \mathrm{H}_{2} \mathrm{O}, 1$ $\mathrm{MgCl}_{2}{ }^{*} 6 \mathrm{H}_{2} \mathrm{O}, 20$ tetraethylammonium chloride, 54 -aminopyridine. Three hundred fifty-micrometer-thick coronal slices containing the amygdala were cut using a vibratome (Microm). The slices were placed in a holding chamber containing the aforementioned gassed $\mathrm{ACSF}$ and held at room temperature for at least $1 \mathrm{~h}$. Immediately before recording, slices were transferred to a recording chamber mounted on an upright microscope (BX50WI, Olympus) and superfused with gassed ACSF. All experiments were done at room temperature $\left(22-24^{\circ} \mathrm{C}\right)$. Patch pipettes were pulled from borosilicate glass capillaries and had a resistance of 3-7 M $\Omega$. All recordings were performed with a HEKA EPC 9 amplifier. Data were acquired, processed, and analyzed using Pulse (HEKA) and either Microsoft Excel 2000 or Origin 7.5 (OriginLab) software.

\section{$\mathrm{Ba}^{2+}$ current recordings}

In $\mathrm{Ba}^{2+}$ current recordings, electrodes were filled with the following (in mM): 120 Cs-methanesulfonate, 10 EGTA, $5 \mathrm{Mg}$-ATP, $0.5 \mathrm{Na}_{3}$-GTP, 20 HEPES, $0.5 \mathrm{CaCl}_{2}, 10 \mathrm{NaCl}$, adjusted to $\mathrm{pH} 7.3$ with CsOH. During recordings, $1 \mu \mathrm{M}$ TTX was applied to all bath solutions to block sodium currents. Pyramidal neurons of the LA were identified by visual characteristics and patched in whole-cell mode. Signals where digitized at $4 \mathrm{kHz}$ and filtered at $2 \mathrm{kHz}$. Cells where held at $-60 \mathrm{mV}$ and depolarized every $30 \mathrm{~s}$ to $-5 \mathrm{mV}$, a pulse lasting $100 \mathrm{~ms}$. After at least $10 \mathrm{~min}$ of achieving a stable baseline, the solution was slowly $(1 \mathrm{ml} / \mathrm{min})$ replaced by ACSF additionally containing $20 \mu \mathrm{m}$ isradipine.

\section{$L T P$ recordings}

In LTP experiments, recording electrodes were filled with the following (in mM): $130 \mathrm{~K}$-gluconate, $0.6 \mathrm{EGTA}, 5 \mathrm{KCl}, 2 \mathrm{MgCl}^{*} 6 \mathrm{H}_{2} \mathrm{O}, 10 \mathrm{HEPES}, 2$ $\mathrm{Mg}$-ATP, $0.3 \mathrm{Na}_{3}$-GTP, adjusted to $\mathrm{pH}$ 7.3. To identify and characterize pyramidal neurons of the LA electrophysiologically, cells were held under current-clamp conditions at $0 \mathrm{pA}$. The resulting resting potentials were $-63 \mathrm{mV} \pm 1.4 \mathrm{mV}$ in Ctr neurons. There was no significant change in resting potentials in neurons from other animal lines or treatment groups. Next, cells were given 800 -ms-long current injections in $10 \mathrm{pA}$ steps ranging from -20 to $80 \mathrm{pA}$. Upon reaching their spiking threshold, cells produced an action potential (AP) firing pattern that elicited frequency adaptation, which is typical for pyramidal neurons of the LA
(Weisskopf and LeDoux, 1999). For each cell, the first current-injection trace that induced an AP train of at least three spikes was analyzed (see Fig. 1c). Frequency adaptation values were calculated by division of the time interval between the second and the third action potential by the time interval between the first and the second action potential. Spiking latency was measured as the latency for the onset of the first action potential. Pyramidal neurons from the different experimental groups were analyzed for their spiking latency and frequency adaptation values, which are given in Table 1, together with their spiking threshold, resting potential, and input resistance values.

In the LTP induction protocol, cells where held at $0 \mathrm{pA}$ under currentclamp conditions. Cells where stimulated presynaptically via thalamic afferents into the LA (see Fig. 1b) through a $5^{\prime \prime}$ concentric bipolar tungsten electrode (stimulus length $150 \mu \mathrm{s}$, catalog TM53CCINS, World Precision Instruments). Presynaptic stimulation was set to induce $30-50 \%$ of the EPSP maximum. Baseline was monitored by applying a test stimulus every $15 \mathrm{~s}$. For analysis, values were binned into 1 min intervals. After 5 min of achieving a stable baseline, cells were given a 100-ms-long $100 \mathrm{~Hz}$ tetanus presynaptically paired with postsynaptic current injection to depolarize them toward their spiking threshold. This stimulation train was repeated 10 times with a $10 \mathrm{~s}$ interval (see Fig. $1 b$ ). After LTP induction, test stimuli were given every $15 \mathrm{~s}$ for $30 \mathrm{~min}$. Values were binned into $1 \mathrm{~min}$ intervals and expressed as percentage to the averaged baseline value. All drugs were added to the ACSF before the beginning of the respective recording. For analysis, the values recorded during the whole $30 \mathrm{~min}$ of the recording session (after potentiation) were averaged into a single score for each cell. The amount of potentiation was analyzed by comparing preinduction values (average of the $5 \mathrm{~min}$ before induction) with those collected during the $30 \mathrm{~min}$ after LTP induction. Significance of potentiation relative to baseline (100\%) was tested with a Wilcoxon signed rank test. Comparison of the amount of potentiation between groups (drug treatments or genotypes) was tested using oneway ANOVA with Tukey's post hoc test. Differences were considered significant if $p<0.05$.

\section{AMPAR rectification and NMDA currents recordings}

In AMPAR recordings, pipettes contained the following (in $\mathrm{mM}$ ) 135 Cs-methanesulfonate, 0.5 EGTA, 4 Mg-ATP, 0.3 Na3-GTP, 10 HEPES, 8 $\mathrm{NaCl}, 0.3$ QX314, 0.1 spermine-tetrahydrochloride adjusted to $\mathrm{pH}$ 7.3. During AMPA rectification recordings, $0.1 \mathrm{~mm}$ aminophosphonovalerate (APV) and $0.05 \mathrm{~mm}$ picrotoxin were applied to all bath solutions. Principal neurons of the LA were held under voltage-clamp conditions, alternating at $-70 \mathrm{mV}$ and $+40 \mathrm{mV}$, and slices were stimulated via the thalamo-amygdala pathway (see LTP recordings). Five traces per cell were binned.

To estimate possible effects on NMDA currents, APV was excluded from the extracellular solutions to elicit NMDA currents at $+40 \mathrm{mV}$ holding potential, and these solutions were compared with a group of solutions treated with $10 \mu \mathrm{M}$ philanthotoxin-433 (PhTX) (Sigma-Aldrich).

\section{Paired-pulse facilitation}

Picrotoxin $(50 \mu \mathrm{M})$ was added to the extracellular ACSF. Pyramidal neurons of the LA were patched in voltage-clamp configuration as described above. The neurons received two presynaptic stimuli in rapid succession (50 ms interval) to elicit paired pulse facilitation (PPF) of the resulting EPSCs. The degree of facilitation was determined by comparing the EPSC 
amplitude of the second pulse to the amplitude of the first pulse elicited by the PPF protocol.

\section{Auditory fear conditioning behavior assay}

Setup. Experiments were performed in two contexts, the conditioning chamber and the test context, which differed in various aspects, including shape, odor, illumination, and bedding (Kamprath and Wotjak, 2004). Contexts were cleaned thoroughly after each trial, and the bedding was changed.

Procedure. For auditory fear conditioning, animals were placed in the conditioning chamber. After $3 \mathrm{~min}$, a tone ( $9 \mathrm{kHz}, 80 \mathrm{~dB}$ sine wave) was presented for $20 \mathrm{~s}$ that coterminated with a single scrambled electric footshock $(0.70 \mathrm{~mA}, 2 \mathrm{~s})$ administered via the metal grid. Mice remained in the chamber for additional $60 \mathrm{~s}$ after the last shock before they were returned to their home cages.

To analyze freezing to the tone, mice were habituated to the neutral test context for $3 \mathrm{~min}$ and then exposed to a $3 \min$ tone $(9 \mathrm{kHz}, 80 \mathrm{~dB}) 1$ and $7 \mathrm{~d}$ after conditioning. After tone presentation, animals remained in the test context for another $60 \mathrm{~s}$ before being returned to their home cages.

Measurements. Conditioned fear was assessed off-line from video tapes by an experienced observer who quantified the freezing response to the tone (Kamprath and Wotjak, 2004).

Stereotaxic surgery. Surgery was performed under isoflurane anesthesia essentially as described previously (Wanisch and Wotjak, 2008). Briefly, C57/BL/6JOlaHSd mice were fixed to a stereotaxic frame and unilaterally equipped with a 23 gauge stainless steel guide cannula aimed at the right lateral ventricle (coordinates: $0.3 \mathrm{~mm}$ posterior to bregma, $1 \mathrm{~mm}$ lateral from midline, $1.2 \mathrm{~mm}$ below the surface of the skull) (Paxinos, 2001). Mice quickly recovered from surgery and were tested 1 week later.

At the end of each behavioral experiment, mice were killed by an overdose of isoflurane. Nissl staining and light microscopy was used to verify the location of the cannula tips within the lateral ventricular system.

Drug treatment. Isradipine (Tocris Bioscience) was dissolved in 100\% $\mathrm{EtOH}$ and administered intracerebroventricularly as a $2 \mu \mathrm{l}$ bolus with a final concentration of 10 or $100 \mu \mathrm{M}$ in $1 \% \mathrm{EtOH}$ (i.e., vehicle) either 30 min before (under light isoflourane anesthesia) or right after conditioning (without anesthesia), essentially as described previously (Wanisch and Wotjak, 2008).

\section{In situ hybridization}

Brain sections $(16 \mu \mathrm{m})$ were deparaffinized in toluene and rehydrated in a series of ethanols $(100,95,70$, and $50 \%)$. Slides were prehybridized for $3 \mathrm{~h}$ at $42^{\circ} \mathrm{C}$ in hybridization buffer $(10 \mathrm{~mm}$ Tris- $\mathrm{HCl}$, pH 8.0, $1 \mathrm{~mm}$ EDTA, $0.3 \mathrm{M} \mathrm{NaCl}, 50 \mathrm{~mm}$ DTT, $1 \times$ Denhardt's solution, $10 \%$ dextran, and $50 \%$ deionized formamide). $\left[{ }^{35} \mathrm{~S}\right] \mathrm{UTP}$-labeled cRNA probes were transcribed in vitro from fragments including nucleotides 2355-2628 (loop between repeat II and III) of murine $\mathrm{Ca}_{\mathrm{v}} 1.2$ and nucleotides $1846-$ 2101 for murine $\mathrm{Ca}_{\mathrm{v}} 1.3$. All probes were located in regions that are unique between the various calcium channel isoforms. Hybridization proceeded overnight at $55^{\circ} \mathrm{C}$ using each probe at a specific activity of $5 \times$ $10^{6} \mathrm{cpm} / \mathrm{ml}$. The sections were washed twice in $2 \times$ SSC buffer, $1 \mathrm{~mm}$ DTT, $1 \mathrm{~mm}$ EDTA and then incubated in RNase A (20 $\mu \mathrm{g} / \mathrm{ml})$ for $30 \mathrm{~min}$ at room temperature to remove the unbound probe. Subsequently, a high stringency wash was done using two changes of $0.1 \times$ SSC, $1 \mathrm{~mm}$ DTT, $1 \mathrm{~mm}$ EDTA at $65^{\circ} \mathrm{C}$. After dehydration, the slides were exposed to BiomaxMR film (Kodak) for $7 \mathrm{~d}$. For resolution of cellular labeling, slides were coated with liquid film emulsion NTB2 (Kodak) and developed after 6 weeks. Sections were counterstained with hematoxylin-eosin and examined by dark-field and bright-field microscopy. In situ hybridizations were always performed with the corresponding sense cRNA probes on adjacent sections. These control hybridizations showed no signals.

\section{Golgi-Cox stain}

Rapid Golgi-Cox staining was done on whole brains by using the FD Rapid GolgiStain kit (FD NeuroTechnologies) as described by the manufacturer.

\section{Biochemical analysis}

For immunoblotting, frozen tissue samples from different brain areas were pulverized under liquid nitrogen and boiled in $2 \%$ SDS/50 mM Tris for $10 \mathrm{~min}$. The resulting homogenates ( $50 \mu \mathrm{g}$ of protein) were separated by $10 \%$ SDS-PAGE, blotted on a polyvinylidene difluoride membrane (Millipore) and probed with a $\mathrm{Ca}_{\mathrm{v}} 1.2$-specific (Moosmang et al., 2005), GluA1-specific (Calbiochem), or GluA2-specific antibody (Alomone Labs). Equal loading of slots was ascertained by the use of an ERK1/2 (extracellular signal-regulated kinase 1/2) antibody (Millipore). All antibodies were visualized by the ECL system (NEN). Quantifications were done by densitometric scanning of films under linear exposure conditions using Quantity One software (Bio-Rad).

\section{Statistical methods}

Values are given as means \pm SEM; $n$ is the number of experiments, $N$ the number of animals. Statistical differences were determined by ANOVA or Student's unpaired $t$ test, and $p$ values of $<0.05$ were considered statistically significant.

\section{Results}

\section{Hebbian LTP at thalamic input synapses in the LA is LTCC dependent}

Recent findings suggest a direct causal link between long-term synaptic enhancements in the pathways that transmit auditory signals to the LA and fear learning (Sigurdsson et al., 2007). Of the two LTCC subtypes, $\mathrm{Ca}_{\mathrm{v}} 1.2$ and $\mathrm{Ca}_{\mathrm{v}} 1.3$, which are expressed in the brain (Striessnig et al., 2006), the $\mathrm{Ca}_{\mathrm{v}} 1.2$ subtype is highly enriched in the LA (Fig. 1a). This prompted us to investigate whether $\mathrm{Ca}_{\mathrm{v}} 1.2$ is required for Hebbian LTP in afferent inputs to the LA. We examined LTP of the compound EPSP, recorded in current-clamp mode at the thalamo-amygdala synapses of principal pyramidal neurons in murine brain slices. Pyramidal neurons of the LA showed various degrees of spike frequency adaptation (Fig. 1b), typical for this cell type (Weisskopf and LeDoux, 1999). Cellular electrophysiological analysis of these neurons from the various genotypes and pharmacological treatments showed no significant differences (Table 1). LTP was induced by pairing 10 presynaptic stimuli, delivered via the thalamic input into the LA (Fig. 1c) at a frequency of $100 \mathrm{~Hz}$, with current injection through the recording electrode.

We found that LTP was significantly reduced to baseline levels in slices treated with the dihydropyridine (DHP) LTCC blocker isradipine $(10 \mu \mathrm{M})$, compared with vehicle-treated slices (Figs. $1 d, e$ ). During $30 \mathrm{~min}$ after LTP induction, on average the thalamo-amygdala EPSP slope was potentiated to $151.1 \pm 9.8 \%$ in vehicle-treated slices ( 5 cells) and to $110.3 \pm 8.9 \%$ of its baseline value in isradipine-treated slices (six cells; significant difference to vehicle control, ANOVA, $p<0.001$; no significant difference to baseline, Wilcoxon signed rank test, $p>0.2$ ). Mean values for baseline EPSP amplitudes and slopes from all LTP experiments are given in supplemental Table S1, available at www.jneurosci.org as supplemental material. To test whether Hebbian LTP in the LA is codependent on both LTCCs and NR2containing NMDAR, we examined whether application of the selective NR2B antagonist ifenprodil to amygdala brain slices impaired tetanus-induced LTP at thalamic input synapses. Ifenprodil $(10 \mu \mathrm{M})$ blocked LTP relative to control cells (Fig. 1d,e). After running the LTP protocol, the ifenprodil group showed no potentiation $(100.2 \pm 11.9 \%, p>0.5)$ compared with baseline values, differing significantly from vehicle controls $(p<0.001)$. Thus, both LTCCs and NMDARs are necessary for the induction of Hebbian LTP at glutamatergic synapses onto principal pyramidal neurons in the LA. To make sure that isradipine did not affect presynaptic function, we performed paired-pulse experiments using either vehicle or $10 \mu \mathrm{M}$ isradipine. The facilitation 
values for the vehicle group (119.1 \pm $4.6 \%, N=11$ ) were not significantly different from those for the isradipine group $(125.0 \pm 5.4, N=10, p>0.4)$, indicating no effect of isradipine on presynaptic function in our experimental setup (sample traces in Fig. S1, available at www. jneurosci.org as supplemental material).

To test whether isradipine changed membrane excitability, we recorded baseline EPSPs and washed in $10 \mu \mathrm{m}$ isradipine $5 \mathrm{~min}$ after establishing a stable baseline. There were no changes in EPSP baseline values after 10 min of isradipine wash-in, indicating that it does not have an effect on general excitability (see Fig. S2, available at www.jneurosci.org as supplemental material). Next, to genetically dissect which of the brain LTCC subtypes, $\mathrm{Ca}_{\mathrm{v}} 1.2$ or $\mathrm{Ca}_{\mathrm{v}} 1.3$, is involved in Hebbian plasticity, we generated brain-specific conditional knock-out mice lacking $\mathrm{Ca}_{\mathrm{v}} 1.2$ in the LA.

Generation of brain-specific CACNA1C knock-out mice

Mice with a global inactivation of the CACNA1C gene die in utero (Seisenberger et al., 2000). Therefore, we used the Cre recombinase system using Nestin-Cre transgenic mice (Tronche et al., 1999) to create a mouse line with an inactivation of the CACNA1C gene in the whole CNS (Fig. 2a). $\mathrm{Ca}_{\mathrm{v}} 1.2^{\text {NesCre }}$ mice are viable and exhibit normal life expectancy, body weight, and breeding. Their brains did not show any obvious morphological abnormalities (Golgi stain) (Fig. 2b). To exclude the possibility that synaptic plasticity and behavioral phenotypes in $\mathrm{Ca}_{\mathrm{v}} 1.2^{\mathrm{NesCre}}$ animals might be influenced by defects in dendritic growth, arborization, and spine densities, we performed a Sholl analysis (Fig. 2c, panels 1, 2) (Sholl, 1955) and spine count (Fig. $2 c$, panels 3,4 ) on principal hippocampal pyramidal neurons. Compared with the LA, the hippocampus is a clearly organized area of the brain and therefore well suited for dimensional analysis of principal neurons, ensuring a low error margin due to less structural overlap. We confirmed the efficiency of the gene deletion in the $\mathrm{Ca}_{\mathrm{v}} 1.2^{\text {NesCre }}$ mice by immunoblotting extracts from different brain regions. $\mathrm{Ca}_{\mathrm{v}} 1.2$ protein was absent from the hippocampus, neocortex, cerebellum, olfactory bulb, and amygdala of $\mathrm{Ca}_{\mathrm{v}} 1.2^{\mathrm{NesCre}}$ mice (Fig. $2 d, e$ ). The above findings clearly demonstrate the effectiveness and selectivity of the CACNA1C knock-out in $\mathrm{Ca}_{\mathrm{v}} 1.2^{\mathrm{Nes} C r e}$ mice. The mRNA level of $\mathrm{Ca}_{\mathrm{v}} 1.3$ was not changed in $\mathrm{Ca}_{\mathrm{v}} 1.2^{\text {NesCre }}$ mice, and the $\mathrm{Ca}_{\mathrm{v}} 1.3$ protein was not detectable in the amygdala from both control and $\mathrm{Ca}_{\mathrm{v}} 1.2^{\mathrm{NesCre}}$ mice (data not shown). This argues against compensatory changes in the expression of the other brain LTCC subtype (Striessnig et al., 2006) as a possible consequence of the CACNA1C gene inactivation. To demonstrate the loss of

b
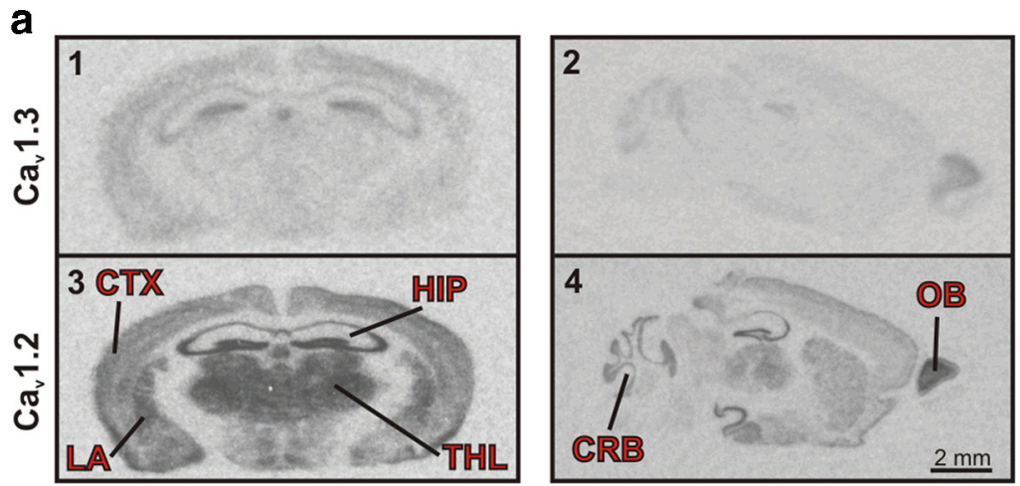

c

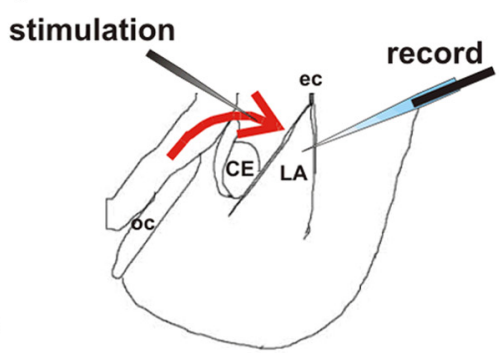

e

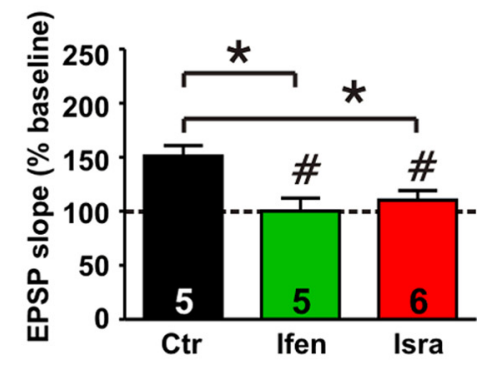

Figure 1. Hebbian LTP in the thalamo-amygdala pathway is LTCC dependent. $\boldsymbol{a}$, Expression of Cav1.x mRNA in the mouse brain . Frontal sections (panels 1 and 3) and sagittal sections (panels 2 and 4) were labeled with a $\mathrm{Ca}_{v} 1.3$-specific (panels 1 and 2) and Ca 1 1.2-specific (panels 3 and 4) probes, as shown. CTX, Cerebral cortex; HIP, hippocampus; THL, thalamus; CRB, cerebellum; OB, olfactory bulb. $\boldsymbol{b}$, Response of a LA cell to current injection of -20 to $50 \mathrm{pA}$. Neural spiking thresholds, resting potentials, spiking latencies, frequency adaptations, and input resistances for each pharmacological or genetic alteration were derived from these traces and are shown in supplemental Table S1, available at www.jneurosci.org as supplemental material. c, Schematic drawing of nucleus of the amygdala; ec, external capsule; oc, optic tract. $\boldsymbol{d}$, The LTCC blocker isradipine (10 $\mu \mathrm{m}$; red) or the NR2B-blocker ifenprodil (10 $\mu \mathrm{M}$, green) abolished the induction of Hebbian LTP (control, black) at thalamic inputs. Time course of normalized are shown. Scale bars: Vertical, $5 \mathrm{mV}$; horizontal, $50 \mathrm{~ms}$. e, Normalized EPSP slope levels averaged over $30 \mathrm{~min}$ after LTP induction. ${ }^{*} p<0.05$ relative to vehicle controls; \#, no significant difference to baseline. Ctr, Vehicle control, Ifen, ifenprodil, Isra, isradipine. Sample sizes are indicated inside the bars.

functional $\mathrm{Ca}_{\mathrm{v}} 1.2$ channels and to characterize a possible contribution of $\mathrm{Ca}_{\mathrm{v}} 1.3$, we assessed isradipine-sensitive $\mathrm{Ba}^{2+}$ inward currents in pyramidal cells of amygdala slices (Fig. $2 f$ ). We added isradipine to the bath perfusion in a high concentration $(20 \mu \mathrm{M})$ to reliably block both the highly DHP-sensitive $\mathrm{Ca}_{\mathrm{v}} 1.2$ and the less sensitive (Striessnig et al., 2006) $\mathrm{Ca}_{\mathrm{v}} 1.3$ subtype. We observed a prominent decrease of the $\mathrm{Ba}^{2+}$ current amplitude (carried by all voltage-gated $\mathrm{Ca}^{2+}$-channel subtypes, including P/Q-type channels) in LA neurons from control mice ( $76 \pm 3 \%$ of baseline; $n=5)$. In sharp contrast, isradipine had no effect (103 $\pm 4 \% ; n=$ 5) on $\mathrm{Ba}^{2+}$ currents in LA neurons of $\mathrm{Ca}_{\mathrm{v}} 1.2^{\mathrm{Nes} C r e}$ mice, indicating that $\mathrm{Ca}_{\mathrm{v}} 1.2$ is the only functionally expressed LTCC subtype 
a

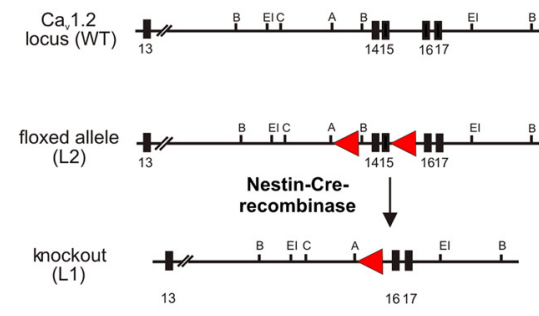

C
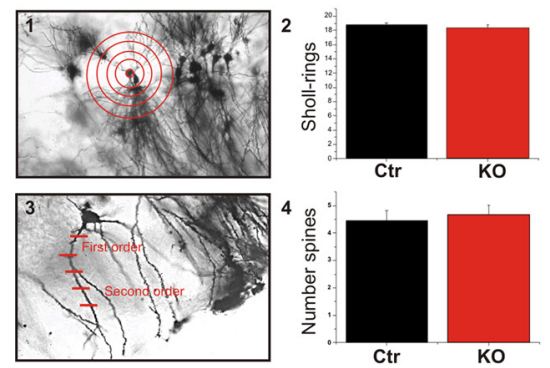

b

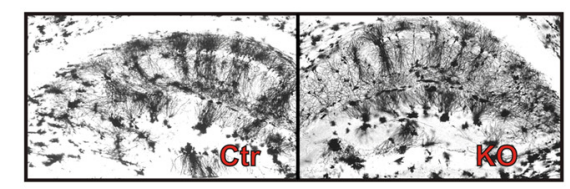

d
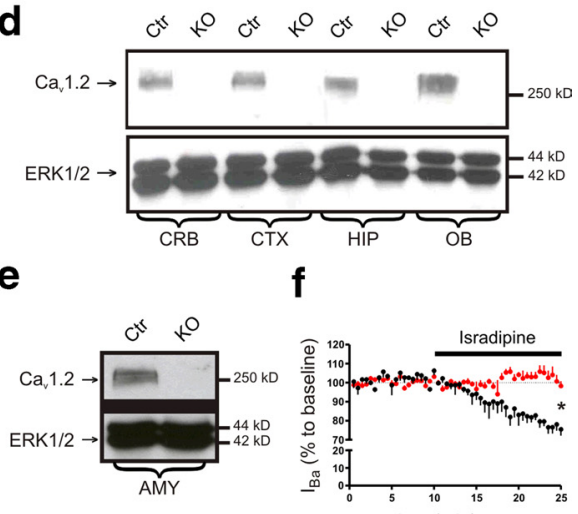

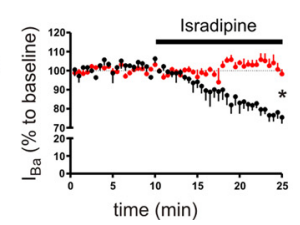

Figure 2. Morphological, biochemical, and cellular electrophysiological characterization of brain-specific $\mathrm{Ca}_{v} 1.2^{\text {Nescre }}$ mice $\boldsymbol{a}$, Schematic representation of the wild type (WT), knock-out (L1), and conditional CACNA1C alleles (L2). The numbers indicate the exon number. Brain-specific activation of Cre recombinase (Nestin-Cre) results in the deletion of CACNA1C exons 14 and 15. Restriction sites are as follows: A, Acc65l; B, BamHI; C, Clal; El, EcoRl; Red triangles, loxP sites. $\boldsymbol{b}$, Golgi-Cox stain demonstrating unchanged dendritic length, branching, and spine density of $\mathrm{Ca}_{v} 1.2^{\text {NesCre }}$ neurons. Ctr, Control; K0, knock-out. c, Analysis of dendritic length and spine number. Panels 1 and 2, Sholl analysis was used to investigate the total dendritic length of hippocampal pyramidal neurons and revealed no differences between the litter-matched controls ( $(\mathrm{tr})$ and $\mathrm{Ca}_{\mathrm{v}} 1.2^{\mathrm{Nes}(\mathrm{re}}$ (KO) groups $(n=10)$. Panels 3 and 4, Analysis of dendrite order and spine number. No differences were found between the two groups in terms of dendritic order (data not shown) or spine number $(n=10)$. $\boldsymbol{d}$, $\boldsymbol{e}$, Western blot analysis of proteins from mouse brain $(\boldsymbol{d})$ or amygdala (e) punches using an anti-Ca 1.2 antibody demonstrates lack of $\mathrm{Ca}_{\mathrm{v}} 1.2$ protein. ERK1/2 was used as loading control. (TX, Cerebral cortex; AMY, amygdale; HIP, hippocampus; CRB, cerebellum; OB, olfactory bulb. kD, kilodalton. $f$, Isradipine ( $20 \mu \mathrm{M}$, solid bar) blocks the DHP-sensitive component of barium currents in Ctr pyramidal neurons of the LA (black; $n=5)$ but has no effect in $\mathrm{Ca}_{\mathrm{v}} 1.2^{\text {NesCre }}$ neurons (red; $\left.n=5\right) .{ }^{*} p<0.05$ relative to baseline.

in the LA and absent in $\mathrm{Ca}_{\mathrm{v}} 1.2^{\mathrm{Nes} C r e}$ mice. Next, we set out to analyze the role of this LTCC for fear memory acquisition using a combination of pharmacological block by intracerebroventricular injections and behavioral screening of $\mathrm{Ca}_{\mathrm{v}} 1.2^{\mathrm{Nes} C r e}$ mice.

\section{Acute pharmacological block of $\mathrm{Ca}_{\mathrm{v}}$ 1.2 LTCCs, but not chronic genetic inactivation, impairs the acquisition of conditioned fear}

With auditory fear conditioning, we investigated a well characterized amygdala-dependent form of associative emotional memory in litter-matched control and $\mathrm{Ca}_{\mathrm{v}} 1.2^{\mathrm{Nes} C r e}$ mice. Fear conditioning involves information of an association between an initially neutral conditioned stimulus (CS), such as tone, and an aversive unconditioned stimulus, such as a foot shock. After fear conditioning, the CS elicits a complex pattern of fear-related behavioral responses, including freezing (Schafe et al., 2001).

Auditory-cued fear memory was assessed $24 \mathrm{~h}$ after conditioning (Fig. 3a). First, separate groups of control mice were given intracerebroventricular injections of vehicle or isradipine as a bolus injection ( $2 \mu \mathrm{l}$ bolus; 10 or $100 \mu \mathrm{M}$ ) either before training (Fig. $3 a$ ) or directly after training (Fig. $3 b$ ). Pretraining injections of $100 \mu \mathrm{M}$ isradipine produced a decrease in the amount of freezing elicited by the tone CS (Fig. 3a). The ANOVA showed a significant effect for group $\left[F_{(2,36)}=10.07 ; p<0.0005\right]$, and Newman-Keuls post hoc tests showed a significant difference between the group that received the highest dose of isradipine compared with the group that received the lower dose and the vehicle group $\left(t_{21}=1.1 ; p<0.01\right)$. Importantly, no differences existed

between groups during baseline freezing after $24 \mathrm{~h}(8.9 \pm 2.3 \%$ vs $9.6 \pm 2.7 \%$ vs third group; $p>0.6)$. Isradipine injections after training produced a different pattern of results (Fig. $3 b$ ). The $t$ test for tone memory scores showed no effect $(p>0.3)$. Thus, a dose of isradipine sufficient to block acquisition of fear conditioning had no effect on consolidation of fear memories.

Next, we investigated whether chronic genetic loss of CACNA1C recapitulates or differs from the effect of acute pharmacological block of the LA LTCC subunit, $\mathrm{Ca}_{\mathrm{v}}$ 1.2. First, we performed a battery of behavioral control tests to rule out unspecific effects of the knock-out on pain perception activity and locomotion, which did not show any differences. Mice of either genotype showed the same pain sensitivity to a rising electric footshock defined as the shock intensity at which mice showed the first signs of discomfort, that is, jumping and/or vocalization $(0.34 \pm 0.05 \mathrm{~mA}$ vs $0.37 \pm 0.07 \mathrm{~mA}, N=$ $5)$. In an open-field locomotor activity test, no significant differences were found, including vertical locomotion (percentage of time spent in the box; $28.2 \pm 2.1 \%$ vs $31.2 \pm 2.1 \%, N=9$ ), resting time, and time spent close to the walls of the box. In a well established rotating rod task (Nolan et al., 2003), there were no differences between genotypes (mean rotation speed at which mice fell from the accelerating rod on day 3, $40.6 \pm 1.8 \mathrm{rpm}$ vs $40.8 \pm 1.1 \mathrm{rpm}, N=10)$. Next, we turned to study auditory fear memory acquisition in $\mathrm{Ca}_{\mathrm{v}} 1.2^{\text {NesCre }}$ mice. Surprisingly, in contrast to the data established with isradipine injections, chronic genetic loss of CACNA1C produced no decrease in the amount of freezing elicited by the tone CS $24 \mathrm{~h}$ after training $\left(t_{16}=1.16 ; p=0.14\right)$ (Fig. 3c). Baseline freezing after $24 \mathrm{~h}$ was identical between groups $(5.4 \pm 1.2 \%$ vs $7.3 \pm$ $2.2 \% ; p>0.4)$.

Since such differences between genetically and pharmacologically achieved effects may result from developmental compensation for genetic loss of the target protein by homeostatic mechanisms (Brickley et al., 2001; Davis and Bezprozvanny, 2001; Davis, 2006), we decided to investigate potential changes in Hebbian synaptic plasticity in $\mathrm{Ca}_{\mathrm{v}} 1.2^{\text {NesCre }}$ mice.

\section{Rescue of Hebbian LTP in mice lacking $\mathrm{Ca}_{\mathrm{v}} 1.2$ by a isradipine-insensitive mechanism}

LTP was only partially reduced in slices from $\mathrm{Ca}_{\mathrm{v}} 1.2^{\mathrm{Nes} C r e}$ animals compared with litter-matched controls (ANOVA, $p<0.001$, Tukey's post hoc test), but there was still strong potentiation compared with baseline (Wilcoxon signed rank test, $p<0.02$ in both groups) (Fig. 4a,c). During $30 \mathrm{~min}$ after LTP induction, the thalamo-amygdala EPSP slope was potentiated on average to $153.6 \pm 16.1 \%$ in controls $(n=6)$ and to $130.9 \pm 6.8 \%$ of its baseline value in $\mathrm{Ca}_{\mathrm{v}} 1.2^{\text {NesCre }}$ slices $(n=6)$.

In contrast to litter-matched control mice (also expressing the Cre transgene) (Fig. 4b,c) and BL6 wild-type controls (Fig. 1d), however, application of isradipine to amygdala brain slices of 

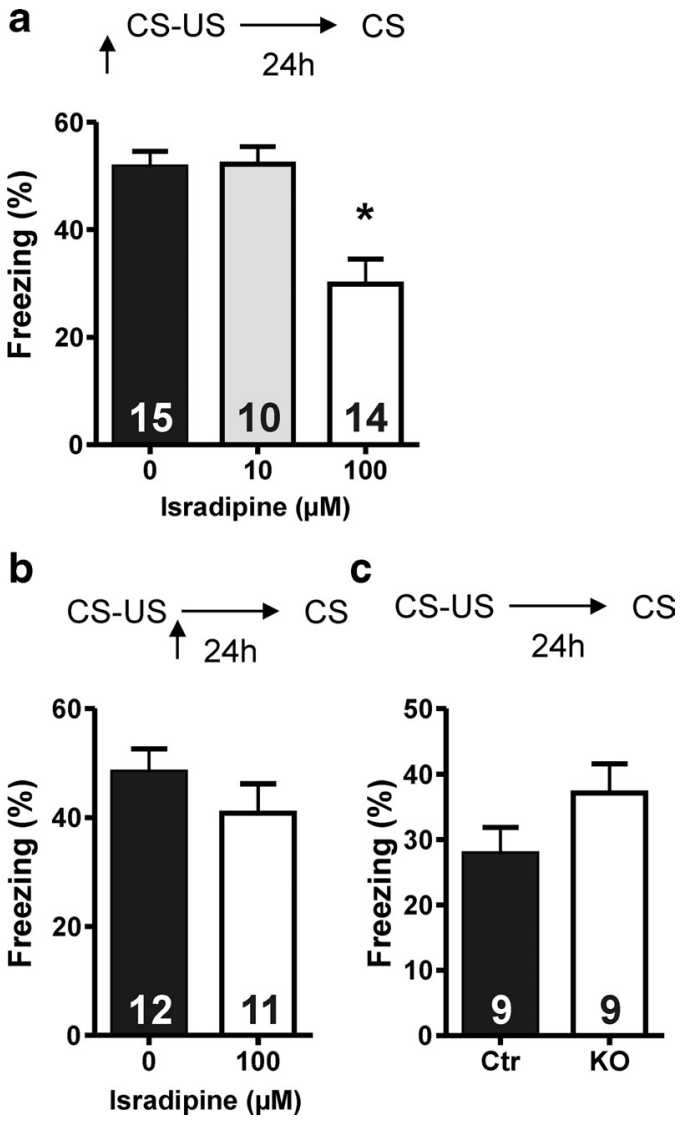

Figure 3. Acute, but not sustained loss of $\mathrm{Ca}^{2+}$ signaling via $\mathrm{Ca}_{\mathrm{v}} 1.2$ impairs acquisition of fear memories. $\boldsymbol{a}, \boldsymbol{b}$, Auditory-cued fear memory $24 \mathrm{~h}$ after conditioning in control mice given intracerebroventricular bolus infusions ( $2 \mu \mathrm{l}$, arrows) of vehicle of isradipine $30 \mathrm{~min}$ before $(\boldsymbol{a})$ or right after conditioning $(\boldsymbol{b}) .{ }^{*} p<0.0005$ relative to vehicle controls. $\boldsymbol{c}$, Auditory-cued fear memory 24 after conditioning in litter-matched $\mathrm{Ctr}_{\text {and }} \mathrm{Ca}_{\mathrm{v}} 1.2^{\text {Nescre }}$ mice. Sample sizes are indicated inside the bars. US, Unconditioned stimulus.

$\mathrm{Ca}_{\mathrm{v}} 1.2^{\mathrm{Nes} C r e}$ animals had no effect on LTP at thalamic input synapses (Fig. $4 b, c)$. The control group treated with isradipine (10 $\mu \mathrm{M})$ showed no LTP $(103.5 \pm 8.8 \%)$, whereas the mechanism of Hebbian LTP in $\mathrm{Ca}_{\mathrm{v}} 1.2^{\mathrm{Nes} C r e}$ slices lost its dependency on LTCCs. In these slices, EPSP slope values after LTP induction were elevated to $132.5 \pm 9.5 \%$ during treatment with isradipine and were significantly different from baseline (Wilcoxon signed rank test, $p<0.02$ ). LTP values of these slices were also different from isradipine-treated litter-matched controls (ANOVA, $p<$ 0.001, Tukey's post hoc test).

Thus, $\mathrm{Ca}^{2+}$ entry through $\mathrm{Ca}_{\mathrm{v}} 1.2$ LTCCs is necessary for the induction of Hebbian LTP in the LA, while sustained loss of $\mathrm{Ca}^{2+}$ entry through $\mathrm{Ca}_{\mathrm{v}} 1.2$ leads to changes in the molecular mechanisms underlying Hebbian synaptic plasticity in the LA. We next set out to analyze the molecular basis of this homeostatic switch.

\section{Sustained loss of $\mathrm{Ca}_{\mathrm{v}} 1.2$ causes Hebbian LTP to switch to a cp-AMPAR-dependent mechanism}

The essential role of $\mathrm{Ca}^{2+}$ signaling in the induction of Hebbian long-term synaptic plasticity (Nicoll and Malenka, 1995) prompted us to investigate potential alternative $\mathrm{Ca}^{2+}$ influx routes as the homeostatically regulated target. Recent findings suggest an important role for GluA1-dependent synaptic plasticity in amygdala-dependent emotional learning (Rumpel et al., 2005; Humeau et al., 2007). In addition, a function of LTCCs for adaption to inactivity (through insertion of cp-AMPAR) in cul-
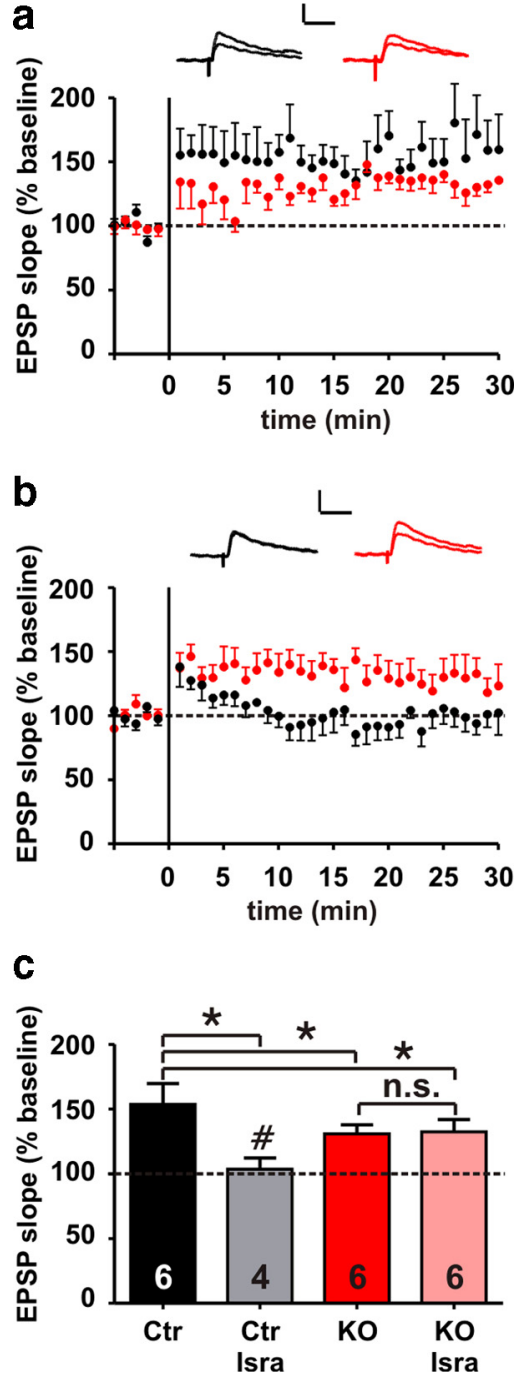

Figure 4. Lack of DHP effect on Hebbian LTP in the thalamo-amygdala pathway in $\mathrm{Ca}_{v} 1.2^{\text {NesCre }}$ mice. $\boldsymbol{a}$, Time course of normalized EPSP slope over 30 min after Hebbian LTP induction in Ctr (black) and $\mathrm{Ca}_{\mathrm{v}} 1.2^{\text {NesCre }}$ (red) LA slices. $\boldsymbol{b}$, Isradipine (10 $\left.\mu \mathrm{m}\right)$ abolished the induction of Hebbian LTP at thalamic inputs in control (black) but not in $\mathrm{Ca}_{v} 1.2^{\text {NesCre }}$ (red) LA slices. Insets $(\boldsymbol{a}, \boldsymbol{b})$ : Traces from individual experiments before and $30 \mathrm{~min}$ after induction are shown. Scale bars: Vertical, $5 \mathrm{mV}$; horizontal, $50 \mathrm{~ms}$. c, Normalized EPSP slope levels averaged over 30 min after LTP induction. Control (Ctr) (black), Ctr plus $10 \mu \mathrm{m}$ isradipine (Isra) (gray), knockout (KO) (Ca $1.2^{\text {NesCre }}$, red), KO plus $10 \mu \mathrm{m}$ Isra (pink), ${ }^{*} p<0.05$ relative to control slices; $\#$, no significant difference to baseline. n.s., no significant difference between $\mathrm{KO}$ and $\mathrm{KO}$ plus Isra groups. Sample sizes are indicated inside the bars.

tured hippocampal neurons has been described (Thiagarajan et al., 2005). Therefore, we hypothesized that increased expression of GluA1-containing, GluA2-lacking cp-AMPAR might be the mechanism of DHP-insensitive Hebbian LTP in $\mathrm{Ca}_{\mathrm{v}} 1.2^{\text {NesCre }}$ mice. In contrast to the majority of AMPARs, which form GluA2containing heteromers, cp-AMPAR is $\mathrm{Ca}^{2+}$-permeable (Geiger et al., 1995) and would thus be ideally suited as a homeostatically regulated alternative source of $\mathrm{Ca}^{2+}$ influx for Hebbian LTP induction.

First, we tested the effect of PhTX, a potent blocker of cpAMPARs (Washburn and Dingledine, 1996), on the DHPinsensitive Hebbian LTP in $\mathrm{Ca}_{\mathrm{v}} 1.2^{\mathrm{Nes} C r e}$ mice. We found that LTP was abolished in slices from $\mathrm{Ca}_{\mathrm{v}} 1.2^{\mathrm{NesCre}}$ mice treated with $10 \mu \mathrm{M}$ PhTX (Fig. 5a,b). On average, during $30 \mathrm{~min}$ after LTP induction the thalamo-amygdala EPSP slope was potentiated 
a

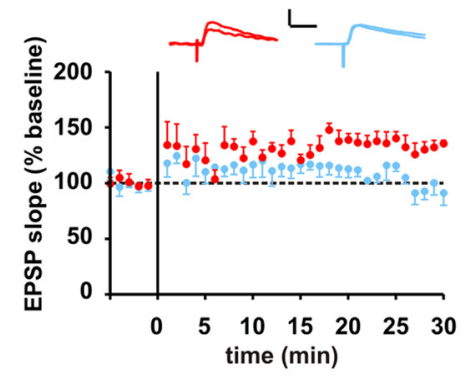

b

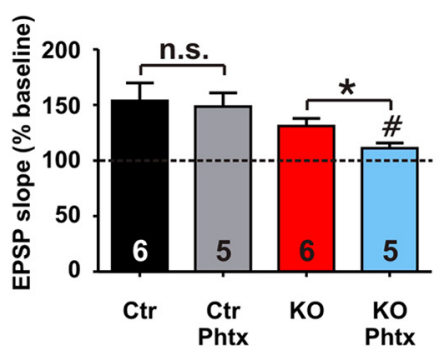

C

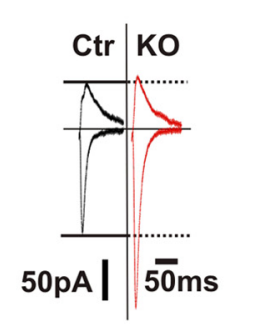

d

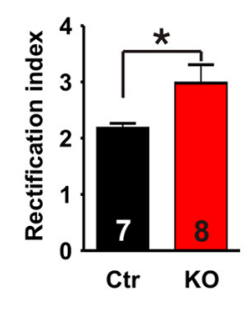

e

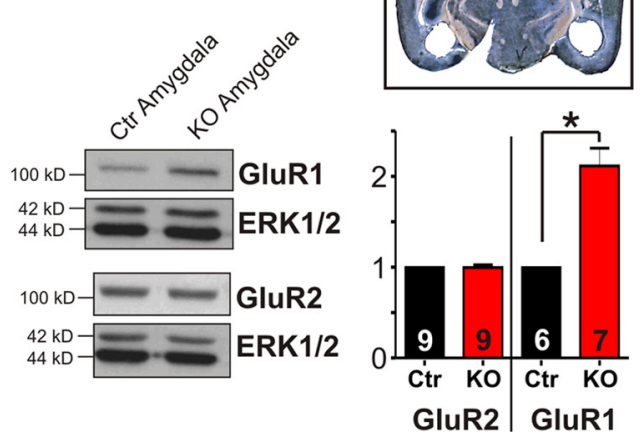

Figure 5. A switch of the mechanism of Hebbian LTP to calcium-permeable AMPA receptors homeostatically compensates for the loss of CACNA1C in Ca $1.2^{\text {Nescre }}$ mice. $\boldsymbol{a}$, Time course of normalized EPSP slope over 30 min after Hebbian LTP induction in $\mathrm{Ca}_{v} 1.2^{\text {Nescre }}(\mathrm{red})$ and philanthotoxin-treated $\mathrm{Ca}_{v} 1.2^{\text {NesCre }}(10 \mu \mathrm{m}$, blue) LA slices. Inset: Traces from individual experiments before and $30 \mathrm{~min}$ after induction are shown. Scale bars: Vertical, $5 \mathrm{mV}$; horizontal 50 ms. $\boldsymbol{b}$, The specific blocker of cp-AMPARs PhTX-433 (10 $\mu \mathrm{m})$ abolished (blue) the induction of Hebbian LTP at thalamic inputs in $\mathrm{Ca}_{\mathrm{y}} 1.2^{\text {Nescre }}$ slices (red) but had no effect on control (Ctr) (black, gray) LA slices. ${ }^{*} p<0.05$ relative to $\mathrm{Ca}_{\mathrm{v}} 1.2^{\text {Nes(re }}$ (K0, knockout) slices; \#, no significant difference to baseline. $c$, Loss of $\mathrm{Ca}_{\mathrm{v}} 1.2$ drives GluA1 into synapses. Averaged examples of evoked AMPA receptor-mediated synaptic responses recorded at $-70 \mathrm{mV}$ and $+40 \mathrm{mV}$ from control LA pyramidal neurons (black) and $\mathrm{Ca}_{v} 1.2^{\text {Nescre }}$ cells (red). $\boldsymbol{d}$, Average rectification index values $\left(I_{-70 \mathrm{mv}} / I_{+40 \mathrm{my}}\right)$ for control and $\mathrm{Ca}_{\mathrm{v}} 1.2^{\text {Nescre }}$ neurons. ${ }^{*} p<0.05, t$ test). $\boldsymbol{e}$, Left: RepresentativeWestern blots of GluA1 and GluA2 in control and $\mathrm{Ca}_{v} 1.2^{\text {Nescre }}$ amygdala punches (top). ERK1/2 was used as a loading control. Right: Quantitative analysis of Western blot signal intensities (normalized to controls) shows that GluA1 levels were increased in $\mathrm{Ca}_{v} 1.2^{\text {Nescre }}$ mice $\left({ }^{*} p<0.001\right.$, $t$ test), while GluA2 levels were unchanged. Sample sizes are indicated inside the bars.

to $111.0 \pm 4.7 \%$ of its initial value in slices treated with PhTX (six cells), which was not significantly different from baseline (Wilcoxon signed rank test, $p>0.1$ ) and significantly less than the untreated $\mathrm{Ca}_{\mathrm{v}} 1.2^{\mathrm{NesCre}}$ group (ANOVA, $p<0.001$ ). Contrar- ily, washing in $10 \mu \mathrm{M}$ PhTX 5 min after induction failed to affect LTP (Fig. S3, available at www.jneurosci.org as supplemental material). Since block of cp-AMPARs eliminated LTP induction in $\mathrm{Ca}_{\mathrm{v}} 1.2^{\text {NesCre }}$ mice, we next evaluated whether PhTX might also block Hebbian plasticity in control mice. However, slices from litter-matched control animals showed robust LTP under PhTX treatment (148.3 $\pm 12.4, p<0.05$ to baseline) (Fig. $5 b)$, which was not different from that of untreated control animals (153.6 \pm 16.1, ANOVA, $p>0.8$ ). Our experiments thus far suggest a pivotal role for cp-AMPARs in $\mathrm{Ca}_{\mathrm{v}} 1.2$-mediated homeostatic changes. The most straightforward hypothesis is that a large increase in homomeric GluA1 receptors takes place at $\mathrm{Ca}_{\mathrm{v}} 1.2^{\mathrm{Nes} C \mathrm{Cre}}$ synapses, accounting for the PhTX-sensitive Hebbian LTP. Therefore, we looked at the rectification of AMPAR-mediated synaptic currents (Fig. 5c).

AMPARs lacking GluA2 show pronounced inward rectification due to voltage-dependent block of the channel pore by polyamines at positive membrane potentials (Bowie and Mayer, 1995; Kamboj et al., 1995; Koh et al., 1995). Thus, to probe $\mathrm{Ca}_{\mathrm{v}} 1.2^{\text {NesCre }}$ synapses for changes in their GluA2 content, we monitored the rectification properties of AMPAR-mediated EPSCs during whole-cell patch-clamp recordings with spermine-containing intracellular solution. Cells were presynaptically stimulated via the thalamic input into the LA while being held at alternating holding potentials of either -70 or $+40 \mathrm{mV}$. Notably, in $\mathrm{Ca}_{\mathrm{v}} 1.2^{\text {NesCre }}$ slices the EPSCs monitored at $-70 \mathrm{mV}$ were significantly increased compared with controls without concomitant changes in EPSC amplitude at $+40 \mathrm{mV}$ (Fig. $5 c$ ). To quantify GluA1 delivery to the thalamo-amygdala synapses, mean rectification indices were calculated: (amplitude at $-70 \mathrm{mV}$ holding potential)/(amplitude at $+40 \mathrm{mV}$ holding potential). Principal pyramidal LA neurons from the $\mathrm{Ca}_{\mathrm{v}} 1.2^{\mathrm{NesCre}}$ group showed a significantly larger index $(3.0 \pm 0.3 ; n=8)$ than neurons from the control group (2.2 $\pm 0.1, p<0.05 ; n=7)$ (Fig. $5 d$ ), indicating increased synaptic delivery of cp-AMPAR through loss of $\mathrm{Ca}_{\mathrm{v}} 1.2$ channels. To discriminate whether NMDAR were affected by the application of PhTX we withheld APV from a number of rectification experiments and compared the values to a group treated only with PhTX. PhTX did not affect NMDA/AMPA ratios in these experiments, indicating that NMDARs were not affected by 10 $\mu \mathrm{M}$ PhTX (see Fig. S4, available at www.jneurosci.org as supplemental material).

Elevated levels of GluA1 favor the formation of cp-AMPAR composed entirely of this subunit (Hollmann and Heinemann, 1994). To substantiate the electrophysiological findings with biochemical data, we checked for alterations in the levels of GluA1 and GluA2. Western blot analysis of GluA1 and GluA2 protein levels was performed on amygdala punch preparations (Fig. 5e). In $\mathrm{Ca}_{\mathrm{v}} 1.2^{\mathrm{Nes} C r e}$ tissue, GluA1 protein levels increased $2.2 \pm 0.2$ fold relative to those in controls $(n=7, p<0.001, t$ test) (Fig. $5 d$ ), while GluA2 levels did not change ( $1.0 \pm 0.02$-fold, $n=9, p>$ $0.95, t$ test) (Fig. $5 d$ ). Thus, both electrophysiological and biochemical data indicate homeostatic changes in GluAl expression in $\mathrm{Ca}_{\mathrm{v}} 1.2^{\mathrm{Nes} C r e}$ mice.

\section{Discussion}

The discrepancy between the clear-cut electrophysiological and biochemical data on neural LTCCs (Dolmetsch et al., 2001, Moosmang et al., 2005, Oliveria et al., 2007, West et al., 2001, Morgan and Teyler, 1999, Weisskopf et al., 1999) and the inconsistent behavioral experiments (Deyo et al., 1989, Bauer et al., 2002, Cain et al., 2002, Moosmang et al., 2005, McKinney et al., 2008) may be explained by the fact that loss of the potentially 
important calcium influx pathway via $\mathrm{Ca}_{\mathrm{v}} 1.2$, as shown here, can also lead to homeostatic changes in synaptic plasticity.

Therefore, we used a careful combination of genetic and pharmacological analyses of $\mathrm{Ca}_{\mathrm{v}} 1.2$ function, taking into account putative metaplastic changes induced by genetic loss of $\mathrm{Ca}_{\mathrm{v}} 1.2$.

The following evidence, presented in the next five paragraphs, demonstrates for the first time that both Hebbian plasticity in the thalamo-amygdala pathway and auditory fear memory acquisition are dependent on the $\mathrm{Ca}_{\mathrm{v}} 1.2$ LTCC subtype.

First, intracerebral injections of the DHP isradipine lead to a dose-dependent impairment of auditory fear learning in mice (Fig. 3a).

Second, isradipine blocked LTP in thalamo-amygdala synapses of pyramidal neurons in the LA (Fig. $1 d, 4 b, c)$. Fear memory acquisition and LTP are therefore dependent on a member of the DHP-sensitive LTCC family, $\mathrm{Ca}_{\mathrm{v}} 1$.x.

Third, $\mathrm{Ca}_{\mathrm{v}} 1.2^{\text {NesCre }}$ pyramidal neurons of the LA lacking $\mathrm{Ca}_{\mathrm{v}} 1.2$ did not show any DHP-sensitive $\mathrm{Ca}^{2+}$ currents (Fig. $2 f$ ). The finding that LTP of $\mathrm{Ca}_{\mathrm{v}} 1.2^{\text {NesCre }}$ pyramidal neurons is DHP insensitive (Fig. $4 b, c$ ) confirms that $\mathrm{Ca}_{\mathrm{v}} 1.3$ has no role for LTP in the LA. Thus, $\mathrm{Ca}_{\mathrm{v}} 1.3$ can be ruled out as possible factor in signal transduction in the LA (in addition, $\mathrm{Ca}_{\mathrm{v}} 1.3$ coding mRNA is only weakly detectable in the LA (Fig. 1a).

Fourth, the lack of DHP effect on synaptic plasticity after loss of $\mathrm{Ca}_{\mathrm{v}} 1.2$ also argues against unspecific modulation of Hebbian plasticity by DHPs.

Fifth, due to homeostatic changes, however, $\mathrm{Ca}_{\mathrm{v}} 1.2^{\mathrm{NesCre}} \mathrm{py}-$ ramidal neurons express a novel form of LTP, which has become vulnerable to cp-AMPAR-specific block by PhTX.

Since $\mathrm{Ca}^{2+}$ signaling is a highly sensitive probe of changes in neural activity, it has long been hypothesized to play an important role in homeostatic plasticity (Davis and Bezprozvanny, 2001). However, it is not clear what the source of $\mathrm{Ca}^{2+}$ relevant to homeostatic signaling in a neuron in a specific pathway is and whether $\mathrm{Ca}^{2+}$-dependent homeostatic mechanisms share signal transduction pathways with Hebbian plasticity phenomena.

Recent seminal data document a role for postsynaptic LTCCs $\left(\mathrm{Ca}_{\mathrm{v}} 1.2\right.$ and/or $\left.\mathrm{Ca}_{\mathrm{v}} 1.3\right)$ for homeostatic adaptation to neural inactivity, indicating that altered $\mathrm{Ca}^{2+}$ entry through these channels is important for the mechanism of homeostatic metaplasticity (i.e., homeostatic changes of the rules governing induction of synaptic plasticity) in cultured hippocampal neurons through insertion of new cp-AMPARs into the postsynapse (Thiagarajan et al., 2005, 2007).

We show that genetic loss of $\mathrm{Ca}_{\mathrm{v}} 1.2$ causes a homeostatic increase in rectification of AMPAR-carried synaptic currents (Fig. 5c) and GluA1 protein expression (Fig. 5e), thus profoundly changing the quality of transmission by rendering AMPARs at the glutamatergic thalamo-amygdala synapses $\mathrm{Ca}^{2+}$-permeable. This switch to $\mathrm{cp}$ AMPARs will introduce a voltage-dependent polyamine block (Plant et al., 2006) and provide an alternative source of ligand-gated $\mathrm{Ca}^{2+}$ signaling for LTP induction (Fig. 5a,b).

The great majority of AMPARs in principal neurons contain GluA2 (Greger et al., 2002), which renders AMPARs impermeable to $\mathrm{Ca}^{2+}$ (Jonas et al., 1994), and NMDARs and voltage-gated $\mathrm{Ca}^{2+}$ channels are thus the major pathways for synaptically evoked $\mathrm{Ca}^{2+}$ entry (Rodrigues et al., 2004). That cp-AMPARs are, in principle, able to mediate Hebbian synaptic plasticity at principal neurons is illustrated by the fact that, in animals with altered GluA2 Q/R editing or knockout, a major fraction of LTP is NMDAR independent (Jia et al., 1996; Feldmeyer et al., 1999).

In addition, at various neural pathways (especially at interneurons with a low baseline GluA2 content), activation of cp-
AMPARs has been shown to lead to Hebbian plasticity under physiological conditions. For example, LTP and LTD at synapses on hippocampal interneurons (Laezza et al., 1999) have been shown to depend on this mechanism.

cp-AMPARs may also play a role in conventional NMDARdependent hippocampal LTP. Following induction of LTP, cpAMPARs were transiently incorporated at the CA1 synapse in hippocampal slice preparations (Plant et al., 2006). However, this hypothesis is disputed (Adesnik and Nicoll, 2007).

The major finding of our study in this context is that a classical glutamatergic, NMDAR-dependent, excitatory synapse of a principal neuron (in the thalamo-amygdala pathway) (Rodrigues et al., 2004), at which cp-AMPARs have no function for Hebbian plasticity under baseline conditions (see lack of effect of PhTX on LTP in controls) (Fig. 5a,b), can be converted into a synapse that depends on cp-AMPARs by homeostatic signaling caused by loss of $\mathrm{Ca}^{2+}$-entry through $\mathrm{Ca}_{\mathrm{v}} 1.2$ channels in vivo.

\section{References}

Adesnik H, Nicoll RA (2007) Conservation of glutamate receptor 2-containing AMPA receptors during long-term potentiation. J Neurosci 27:4598-4602.

Bauer EP, Schafe GE, LeDoux JE (2002) NMDA receptors and L-type voltage-gated calcium channels contribute to long-term potentiation and different components of fear memory formation in the lateral amygdala. J Neurosci 22:5239-5249.

Bowie D, Mayer ML (1995) Inward rectification of both AMPA and kainate subtype glutamate receptors generated by polyamine-mediated ion channel block. Neuron 15:453-462.

Brickley SG, Revilla V, Cull-Candy SG, Wisden W, Farrant M (2001) Adaptive regulation of neuronal excitability by a voltage-independent potassium conductance. Nature 409:88-92.

Busquet P, Hetzenauer A, Sinnegger-Brauns MJ, Striessnig J, Singewald N (2008) Role of L-type $\mathrm{Ca}^{2+}$ channel isoforms in the extinction of conditioned fear. Learn Mem 15:378-386.

Cain CK, Blouin AM, Barad M (2002) L-type voltage-gated calcium channels are required for extinction, but not for acquisition or expression, of conditional fear in mice. J Neurosci 22:9113-9121.

Davis GW (2006) Homeostatic control of neural activity: from phenomenology to molecular design. Annu Rev Neurosci 29:307-323.

Davis GW, Bezprozvanny I (2001) Maintaining the stability of neural function: a homeostatic hypothesis. Annu Rev Physiol 63:847-869.

Deisseroth K, Mermelstein PG, Xia H, Tsien RW (2003) Signaling from synapse to nucleus: the logic behind the mechanisms. Curr Opin Neurobiol 13:354-365.

Deyo RA, Straube KT, Disterhoft JF (1989) Nimodipine facilitates associative learning in aging rabbits. Science 243:809-811.

Dolmetsch RE, Pajvani U, Fife K, Spotts JM, Greenberg ME (2001) Signaling to the nucleus by an L-type calcium channel-calmodulin complex through the MAP kinase pathway. Science 294:333-339.

Feldmeyer D, Kask K, Brusa R, Kornau HC, Kolhekar R, Rozov A, Burnashev N, Jensen V, Hvalby O, Sprengel R, Seeburg PH (1999) Neurological dysfunctions in mice expressing different levels of the $\mathrm{Q} / \mathrm{R}$ site-unedited AMPAR subunit GluR-B. Nat Neurosci 2:57-64.

Geiger JR, Melcher T, Koh DS, Sakmann B, Seeburg PH, Jonas P, Monyer H (1995) Relative abundance of subunit mRNAs determines gating and $\mathrm{Ca}^{2+}$ permeability of AMPA receptors in principal neurons and interneurons in rat CNS. Neuron 15:193-204.

Greger IH, Khatri L, Ziff EB (2002) RNA editing at arg607 controls AMPA receptor exit from the endoplasmic reticulum. Neuron 34:759-772.

Grover LM, Teyler TJ (1990) Two components of long-term potentiation induced by different patterns of afferent activation. Nature 347:477-479.

Hollmann M, Heinemann S (1994) Cloned glutamate receptors. Annu Rev Neurosci 17:31-108.

Humeau Y, Reisel D, Johnson AW, Borchardt T, Jensen V, Gebhardt C, Bosch V, Gass P, Bannerman DM, Good MA, Hvalby O, Sprengel R, Luthi A (2007) A pathway-specific function for different AMPA receptor subunits in amygdala long-term potentiation and fear conditioning. J Neurosci 27:10947-10956.

Jia Z, Agopyan N, Miu P, Xiong Z, Henderson J, Gerlai R, Taverna FA, Velumian A, MacDonald J, Carlen P, Abramow-Newerly W, Roder J 
(1996) Enhanced LTP in mice deficient in the AMPA receptor GluR2. Neuron 17:945-956.

Jonas P, Racca C, Sakmann B, Seeburg PH, Monyer H (1994) Differences in $\mathrm{Ca}^{2+}$ permeability of AMPA-type glutamate receptor channels in neocortical neurons caused by differential GluR-B subunit expression. Neuron 12:1281-1289.

Kamboj SK, Swanson GT, Cull-Candy SG (1995) Intracellular spermine confers rectification on rat calcium-permeable AMPA and kainate receptors. J Physiol 486:297-303.

Kamprath K, Wotjak CT (2004) Nonassociative learning processes determine expression and extinction of conditioned fear in mice. Learn Mem 11:770-786.

Koh DS, Burnashev N, Jonas P (1995) Block of native $\mathrm{Ca}^{2+}$-permeable AMPA receptors in rat brain by intracellular polyamines generates double rectification. J Physiol 486:305-312.

Laezza F, Doherty JJ, Dingledine R (1999) Long-term depression in hippocampal interneurons: joint requirement for pre- and postsynaptic events. Science 285:1411-1414.

McKinney BC, Sze W, White JA, Murphy GG (2008) L-type voltage-gated calcium channels in conditioned fear: a genetic and pharmacological analysis. Learn Mem 15:326-334.

Moosmang S, Haider N, Klugbauer N, Adelsberger H, Langwieser N, Muller J, Stiess M, Marais E, Schulla V, Lacinova L, Goebbels S, Nave KA, Storm DR, Hofmann F, Kleppisch T (2005) Role of hippocampal Cav1.2 $\mathrm{Ca}^{2+}$ channels in NMDA receptor-independent synaptic plasticity and spatial memory. J Neurosci 25:9883-9892.

Morgan SL, Teyler TJ (1999) VDCCs and NMDARs underlie two forms of LTP in CA1 hippocampus in vivo. J Neurophysiol 82:736-740.

Nicoll RA, Malenka RC (1995) Contrasting properties of two forms of longterm potentiation in the hippocampus. Nature 377:115-118.

Nolan MF, Malleret G, Lee KH, Gibbs E, Dudman JT, Santoro B, Yin D, Thompson RF, Siegelbaum SA, Kandel ER, Morozov A (2003) The hyperpolarization-activated $\mathrm{HCN} 1$ channel is important for motor learning and neuronal integration by cerebellar Purkinje cells. Cell 115: 551-564.

Oliveria SF, Dell'Acqua ML, Sather WA (2007) AKAP79/150 anchoring of calcineurin controls neuronal L-type $\mathrm{Ca}^{2+}$ channel activity and nuclear signaling. Neuron 55:261-275.

Paxinos G (2001) The mouse brain in stereotaxic coordinates. San Diego: Academic.

Plant K, Pelkey KA, Bortolotto ZA, Morita D, Terashima A, McBain CJ, Collingridge GL, Isaac JT (2006) Transient incorporation of native GluR2-lacking AMPA receptors during hippocampal long-term potentiation. Nat Neurosci 9:602-604.

Rodrigues SM, Schafe GE, LeDoux JE (2004) Molecular mechanisms underlying emotional learning and memory in the lateral amygdala. Neuron 44:75-91.
Rumpel S, LeDoux J, Zador A, Malinow R (2005) Postsynaptic receptor trafficking underlying a form of associative learning. Science 308:83-88.

Schafe GE, Nader K, Blair HT, LeDoux JE (2001) Memory consolidation of Pavlovian fear conditioning: a cellular and molecular perspective. Trends Neurosci 24:540-546.

Seisenberger C, Specht V, Welling A, Platzer J, Pfeifer A, Kuhbandner S, Striessnig J, Klugbauer N, Feil R, Hofmann F (2000) Functional embryonic cardiomyocytes after disruption of the L-type alpha1C (Cav1.2) calcium channel gene in the mouse. J Biol Chem 275:39193-39199.

Sholl DA (1955) The organization of the visual cortex in the cat. J Anat 89:33-46.

Sigurdsson T, Doyere V, Cain CK, LeDoux JE (2007) Long-term potentiation in the amygdala: a cellular mechanism of fear learning and memory. Neuropharmacology 52:215-227.

Striessnig J, Koschak A, Sinnegger-Brauns MJ, Hetzenauer A, Nguyen NK, Busquet P, Pelster G, Singewald N (2006) Role of voltage-gated L-type $\mathrm{Ca}^{2+}$ channel isoforms for brain function. Biochem Soc Trans 34: 903-909.

Suzuki A, Josselyn SA, Frankland PW, Masushige S, Silva AJ, Kida S (2004) Memory reconsolidation and extinction have distinct temporal and biochemical signatures. J Neurosci 24:4787-4795.

Thiagarajan TC, Lindskog M, Tsien RW (2005) Adaptation to synaptic inactivity in hippocampal neurons. Neuron 47:725-737.

Thiagarajan TC, Lindskog M, Malgaroli A, Tsien RW (2007) LTP and adaptation to inactivity: overlapping mechanisms and implications for metaplasticity. Neuropharmacology 52:156-175.

Tronche F, Kellendonk C, Kretz O, Gass P, Anlag K, Orban PC, Bock R, Klein $\mathrm{R}$, Schutz G (1999) Disruption of the glucocorticoid receptor gene in the nervous system results in reduced anxiety. Nat Genet 23:99-103.

Waltereit R, Mannhardt S, Nescholta S, Maser-Gluth C, Bartsch D (2008) Selective and protracted effect of nifedipine on fear memory extinction correlates with induced stress response. Learn Mem 15:348-356.

Wanisch K, Wotjak CT (2008) Time course and efficiency of protein synthesis inhibition following intracerebral and systemic anisomycin treatment. Neurobiol Learn Mem 90:485-494.

Washburn MS, Dingledine R (1996) Block of alpha-amino-3-hydroxy-5methyl-4-isoxazolepropionic acid (AMPA) receptors by polyamines and polyamine toxins. J Pharmacol Exp Ther 278:669-678.

Weisskopf MG, LeDoux JE (1999) Distinct populations of NMDA receptors at subcortical and cortical inputs to principal cells of the lateral amygdala. J Neurophysiol 81:930-934.

Weisskopf MG, Bauer EP, LeDoux JE (1999) L-type voltage-gated calcium channels mediate NMDA-independent associative long-term potentiation at thalamic input synapses to the amygdala. J Neurosci 19:10512-10519.

West AE, Chen WG, Dalva MB, Dolmetsch RE, Kornhauser JM, Shaywitz AJ, Takasu MA, Tao X, Greenberg ME (2001) Calcium regulation of neuronal gene expression. Proc Natl Acad Sci U S A 98:11024-11031. 